\title{
REVIEW OF CHARACTERISTIC FEATURES OF ABHRAKA WSR TO PINAKA ABHRAKA
}

\author{
JAY PRAKASH GUPTA, MANISHA GOYAL*, RAJARAM AGARWAL
}

Department of Rasashastra and Bhaishajya Kalpana, Dr Sarvepalli Radhakrishnan Rajasthan Ayurved University, Jodhpur, Rajasthan, India. Email: manishagoyal29@gmail.com

Received: 07 October 2020, Revised and Accepted: 21 December 2020

ABSTRACT

Rasashastra (Vedic chemistry) is the root branch of the Ayurveda (the science of life) that deals with herbomineral preparations. Abhraka (mica) is a mineral that classified in Maharasa group of Rasashastra. The mica is basically consist of various metals in oxide form as minerals in different ratio, were the percentage of the form varies based on the origin of base. It contains several elements such as $\mathrm{Si}, \mathrm{Fe}, \mathrm{Al}, \mathrm{Mg}$, $\mathrm{Na}$, and $\mathrm{K}$ as main ingredients. Four types of abhrakas are described in the Classics of Rasashastra including pinaka. Property of Pinaka is told that when it is heated on fire, the layers get separates. Intake of its bhasma causes severe constipation. The characteristic effect of pinak abhraka can be correlated with muscovite - paragonite micas because their perfect basal cleavage allows them to split into thin, flexible sheets. Muscovite-paragonite series group of mica having hydrous potassium, sodium, aluminum, and silicate minerals. In this hydrous group, aluminum hydroxide causes constipation. In this paper, an attempt will be made to explain how does pinaka abhrak causes severe constipation.

Keywords: Abhrak, Pinak, Constipation, Hydroxide group, Aluminum hydroxide.

\section{INTRODUCTION}

Ayurveda - literally means the science of life and believed that it exists as long as the origin of life on this earth. It attributes primary importance to the maintenance of positive health and to cure the disease $[1,2]$. Rasashastra or the Ayurvedic alchemy is an important branch of Ayurved. This branch mainly deals with formulation, processing and use of metals, minerals, and gemstones [3]. In the ancient Ayurved, the emphasis has been made over the herbs and their therapeutic uses. Later on, the animal products, metals, and minerals started to find favor of the Ayurvedic practitioners. Metals and minerals were proved to be very potent in terms of immunization, rejuvenation, and the elimination of diseases [4]. In new trends, the term Rasa Shastra has got a wide spectrum and wide dimension for the systemic study of these minerals. In the herbomineral treatments of Ayurveda, the key ingredients of these formulations are bhasmas, which consist of Nano herbal metals. In ayurvedic alchemy, Abhrak is a key mineral described in Maharasa Varga [5-7]. In Maharas Acharya described 8 Dravyas [5], in all of them Abhrak is a prominent dravya and closely resemble to Parad (mercury). It is mentioned as a Gauri Tej in rasa granthas [5].

According to color, there are 4 types of abhrak told by our Rasacharyas such as wize, sweta, pita, rakta, and Krishna [8-10]. In all of them krishnabhraka is best to prepare bhasma [11]. On structural basis, there are four types of abhrak mentioned such as - Pinakabhraka, Nagabhraka, Mandurabhraka, and Vajrabhraka $[5,12,13]$.

Pinaka abhrak is heated on the fire; the layers should be separates and cause severe constipation. The Nagabhraka makes the hissing sound like snake, when keeping on the fire. The Mandukabhraka if heated on fire jump like a frog. The Vajrabhraka does not exhibit any of the characters when subjected to fire $[14,15]$.

In the case of pinaka abhrak rasacharyas says that on heating, the piece of mica starts getting separated and creates a sound that resembles the sound of an arrow and after consuming it will cause severe constipation. However, how it causes constipation is not clearly mentioned.

\section{CALCINATION OR MARANA OF ABHRAK}

Abhrak bhasma is prepared through the process of Marana (incineration) in this process purified mica after sukshmikaran process (size reduction) triturated with plant juices and decoctions. Further triturated material subjected to the calcination process which is called PUTA in Ayurved. The properties of abhrak bhasma depend upon the number of putas. In general, it varies from 1 Puta to 1000 Puta for preparation of abhrak bhasma means that the preparation process involves 1-1000 times repeated calcinations of raw abhrak/mica after triturating it with plant juices and prepared pallets subjected to the drying in sunlight [16].

It is widely used in the treatment of diseases like hepatitis, tuberculosis, asthma, cough, cold, and other respiratory infections. It acts as an excellent cellular regenerator and nervine tonic. It is used in various nervous system diseases such as chronic headache, migraine, dementia, memory loss, epilepsy, anxiety, and mental stress. It is used in the treatment of digestive impairment, malabsorption syndrome, urinary disorders, diabetes, cardiac disorders, and various types of skin conditions and helpful in curing both male and female sexual disorders [17]. It has a great Rejuvenation power works like Amrit [5].

\section{MODERN VIEW OF ABHRAKA (MICA)}

The mica group represents 37 Phyllosilicate minerals that have a layered or platy texture. Mica's value is based on its several unique physical properties. The crystal of mica has layers that can be divided or delaminated in thin sheets resulting in foliation of rocks. Muscovite light-colored mica and biotite, which is typically black or nearly so, are the most abundant. Phlogopite is typically brown, and the appearance of Paragonite is quite similar to muscovite, also are very common. Lepidolite, generally pinkish to lilac in color, occurs in lithium-bearing pegmatites [18]. Muscovite is the most common mineral of the mica family. Like other varieties of micas, it is easily get separated in thin transparent sheets. Muscovite based on its perfect cleavage which makes it split into sleek, flexible, elastic, and colorless, transparent sheets along with a pearly luster makes it easily identifiable. Muscovite is a potassium-aluminum rich mica with the generalized composition $\mathrm{KAl}_{2}\left(\mathrm{AlSi}_{3} \mathrm{O}_{10}\right)(\mathrm{OH})_{2}[19]$.

It can withstand heat up to $600^{\circ} \mathrm{C}$. The water constitution of muscovite is $4.5 \%$. It loses water of the constitution at $600^{\circ} \mathrm{C}$ under this temp., due to the release of water, mica gradually loses its luster and transparency, stratifies, and becomes fragile. It is the only mineral in the mica group 
Table 1: Total oxide present in muscovite mica

\begin{tabular}{ll}
\hline Name of oxide & Quantity \\
\hline $\mathrm{K}_{2} \mathrm{O}$ & $11.81 \%$ \\
$\mathrm{Al}_{2} \mathrm{O}_{3}$ & $38.36 \%$ \\
$\mathrm{SiO}_{2}$ & $45.21 \%$ \\
$\mathrm{H}_{2} \mathrm{O}$ & $4.07 \%$ \\
$\mathrm{~F}$ & $0.95 \%$ \\
\hline
\end{tabular}

that can be split easily into films of $0.001^{\prime \prime}$ or thinner because it has such excellent cleavage.

The thermal decomposition of muscovite is dominated by the presence initially of the three-layered mica structure. Initially, $\mathrm{Al}_{2} \mathrm{O}_{3}$ and then corundum form from the octahedrally coordinated aluminous sheet which is sandwiched by two tetrahedral sheets. With potassium from the interlayer site, the tetrahedral sheets break down to form a melt, from which leucite crystallizes [20].

\section{RESULTS AND DISCUSSION}

By consuming, pinaka abhrak will get severe constipation and Nagabhrak causes mandala kushtha when it is consumed. Mandukabhrak takes internally, causes incurable asmari disease, which was removed by surgical measures. Krishnabhrak is the best variety and gives strength to the body like iron $[14,21]$

we can correlate pinaka abhrak with muscovite - paragonite series mica, due to its characteristic feature split into thin sheets at $600{ }^{\circ} \mathrm{c}$ temp and initially $-\mathrm{KAl}_{2}\left(\mathrm{AlSi}_{3} \mathrm{O}_{10}\right)(\mathrm{OH})_{2}$ gives $\mathrm{Al}_{2} \mathrm{O}_{3}$ or $\mathrm{Al}(\mathrm{OH})_{3}$ According to Research, this mica has $38.36 \%$ aluminum ions [22] [Table 1].

Aluminium causes constipation, magnesium induces diarrhea, because aluminium ions inhibit the contration of smooth muscle cells in the gastrointestial tract, slowing peristalsis and lengthening the time needed for stool to pass through the colon thus it results in hardening of stool present in the rectum eventually causing feacal impaction. Aluminum inhibits the motor activity of the stomach and intestine. The most frequent adverse effect of aluminum antacids is constipation. Constipation is defined as unsatisfactory defecation which is characterized by infrequent bowel movements, difficulty in passing stool or both. Decreased bowel motility, dehydration, or fluid restriction may predispose patients to intestinal obstruction [24].

Among the various aluminum salts, hydroxide is a compound which is present in many antacids. Aluminum hydroxide is not an easily soluble compound and it forms polymers of varied compositions. It has a weaker effect and it is a slower acid-neutralizer. With a pHvalue of over 3 , it also adsorbs pepsin together with phosphate and bile salts, it forms an insoluble compound. Aluminum hydroxide displayed the greatest bile acid-binding for all individual bile acids both in aqueous solutions as well as in gallbladder bile, and the degree of binding was comparable to that of cholestyramine. Dihydroxy bile acids (chenodeoxycholate and deoxycholate) were strongly binding to aluminum hydroxide. Aluminum ions cause the relaxation of the gastrointestinal smooth muscle, which can postpone gastric emptying and can cause constipation [25]. Hence, aluminum ions increased stool bulk and harder stool consistency. This may trigger or aggravate intestinal obstruction and ilio-intestinal obstruction leads to fecal impaction. Fecal impaction is defined as a compacted, immovable mass of feaces filling the rectum. Feacal impaction causes the intraluminal pressure within the colon to increase and exceed the capillary perfusion pressure in the bowel wall and eventually in ulceration and perforation. Intense red or black colored stools, coughing up blood or vomit that appears like coffee grounds. Later on, it may cause death.

\section{CONCLUSION}

According to the above discussion, it has scientifically proved that due to the presence of aluminum ions, pinaka abhraka causes fecal impaction or chronic constipation, and this was said by our Acharyas before since thousands of year.

\section{REFERENCES}

1. Shastri K. Caraka Samhita Purvardh, Part-1. Ch. 30. Varanasi: Chaukhambha Bharati Academy; 2013. p. 587.

2. Shasrti A, Samhita S. Chaukhambha Samskrita Sansthan. Vol. 1., Ch. 1. Varanasi: Sutra Sthana; 2018. p. 7.

3. Kulkarni DA. Rasaratnasamuccaya. Vol. 1., Ch. 1. New Delhi Meharchand Lachhmandas Publications; 2017. p. 1.

4. Meena M. Ayurvediya Rasshastra. Ch. 1. Jaipur: Jagdish Sanskrit Pustakalaya; 2013. p. 16.

5. Kulkarni DA. Rasaratnasamuccaya. Vol. 1., Ch. 2. New Delhi: Meharchand Lachhmandas Publications; 2017. p. 18.

6. Mishra S, Sudhakar R. Chaukhambha Orientalia. Ch. 5. Varanasi: Chaukhambha Bharati Academy; 2013. p. 90.

7. Mishra S. Rasapaddhati, Chaukhambha Orientalia. Varanasi: Maharas Varg; 2013. p. 80.

8. Kulkarni DA. Rasaratnasamuccaya. Vol. 1., Ch. 2. New Delhi: Meharchand Lachhmandas Publications; 2017. p. 20.

9. Shastri PK. Rastarangani. Ch. 10. Varanasi: Motilal Banarasidas; 2014. p. 221.

10. Reddy PS. A Text Book of Rasshastra, Part-B. Ch. 1. Varanasi: Chaukhambha Orientalia; 2017. p. 169.

11. Shastri PK. Rastarangani. Ch. 10. Varanasi: Motilal Banarasidas; 2014. p. 223.

12. Shastri PK. Rastarangani. Ch. 10. Varanasi: Motilal Banarasidas; 2014. p. 222.

13. Mishra G. Ayurved Prakash. Ch. 2. Varanasi: Chaukambha Bharati Academy; 2016. p. 280.

14. Kulkarni DA. Rasaratnasamuccaya. Vol. 1., Ch. 2. New Delhi: Meharchand Lachhmandas Publications; 2017. p. 19.

15. Mishra S. Ayurvedeeya Rasashastra. Ch. 3. Varanasi: Chaukhambha Orientalia; 2018. p. 299

16. Mishra G. Ayurved Prakash. Ch. 2. Varanasi: Chaukambha Bharat Academy; 2016. p. 286-91.

17. Shastri PK. Rastarangani. Ch. 10. Varanasi: Motilal Banarasidas; 2014. p. 234-5.

18. Dietrich RV. Mica, Encyclopedia Britanica; 2020. Available from: http:/ www.britannica.com/science/mica. [Last accessed on 2020 Aug 23].

19. King HM. Muscovite. Available from: https://www.geology.com/ minerals/muscovite.sht. [Last accessed on 2020 Aug 19].

20. Barlow SG, Manning DA. Influence of Time and Temperature on Reactions and Transformations of Muscovite Mica. British Ceramic Transactions; 1999. Available from: http://www.tandfoline.com. [Last accessed on 2020 Aug 10].

21. Reddy PS. A Text Book of Rasshastra, Part-B. Ch. 1. Varanasi: Chaukhambha Orientalial; 2017. p. 169.

22. Muscovite Mineral Data. Available from: http://www.webmineral.com. [Last accessed on 2020 Sep 18].

23. Wienbeck M, Erckenbrecht J, Strohmeyer G. Wirkung von Antazida Auf die Darmmotilitat [Effects of antacids on intestinal motility]. Z Gastroenterol. 1983;21:111-6.

24. Brandt LJ, Prather CM, Quigley EM, Schiller LR, Schoenfeld P, Talley NJ. A systematic review on the management of chronic constipation in North America. Am J Gastroenterol 2005;100 Suppl 1:S5-21.

25. Aluminium Hydroxide Pharmacology. Available from: http://www. informed.ch. 